\title{
Students' Perception Toward the Implementation of Blended Learning for Teaching ESP in Faculty of Engineering
}

\author{
Sita Nurmasitah ${ }^{1}$, Abdurrachman Faridi $^{2}$, Pudji Astuti ${ }^{1}$, and Siti Nurrohmah ${ }^{1}$ \\ ${ }^{l}$ Department of Home Economics, Faculty of Engineering, Universitas Negeri Semarang \\ ${ }^{2}$ Deparment of English Education and Literature, Faculty of Languages and Arts, Universitas Negeri Semarang \\ Sita_nurmasita@mail.unnes.ac.id
}

Keywords: Students' perception, blended learning, ESP.

\begin{abstract}
With the rapid movement of technology, teaching and learning process will no longer limited by the place and time. Universitas Negeri Semarang (UNNES) as a higher education institution encourages its lecturers and students to use Elena (UNNES e-learning system) or other Learning Management System (LMS) for applying blended learning model in the learning process. This study exposed 145 Faculty of Engineering undergraduate student responses to a blended learning model applied in English for Specific Purposes (ESP) class. The data was taken by using Likert scale questionnaire. As the result, the implementation of blended learning received a positive response in several ways, like the practicality of sharing material, independent learning, and saving time and costs in the learning process. However, some of the students considered to be in a conventional model of learning with several reasons, such as the limited facilities and the technology illiteracy.
\end{abstract}

\section{INTRODUCTION}

The development of technology in this industrial revolution 4.0 era gives a significant impact in education. The use of electronic devices and internet has been increased since the teaching and learning process should be adapted to the transformation of the students' characteristics and behaviours (Puncreobutr, 2016). Gen Zs generation exists as the students in higher education nowadays. This generation was born in 1995 through 2010 who has been shaped by the advancement of technology (Grace, 2017) and rely on the mobile technology (Shatto \& Erwin, 2016). This condition of students encourages education stakeholders to creatively utilize technology for the learning instructional media.

Blended learning's popularity is also increased since the use of advanced technology has been spread out these days, including in higher education. Blended learning defines as the combination of different instructional methods; face to face instruction and computer-mediated instruction or online teaching (Boelens, R et al., 2015; Ardana et al.,
2016; El-Zeftawy \& Hassan, 2017). O'Flaherty \& Phillips (2015) stated the students in blended learning received instruction in classroom by having face to face instruction and required to do the activities outside classroom by using a range of technology resource. In a simple way, blended learning can be defined as the combination of online and offline learning.

Research in blended learning has been conducted and the results shows positives impacts of it. A survey conducted by The Centre for Digital Education found that blended learning offers alternate learning opportunities, offers distance learning to a board-base number of individuals, promotes more student engagement, helps to increase academic achievement, helps to increase classroom capacity, increases student retention, and decreases cost (Hilliard, 2015). Moreover, Lalima and Dangwal (2017) describes the advantages of blended learning; teachers and students get more time in the classroom for creative and cooperative exercise, students gain advantage of online learning and CAI without losing social interaction element and human touch of traditional teaching, it provides more scope for communication, students become more techno savvy 
and they gain enhanced digital fluency, students have more strengthened professionalism as they develop qualities like self-motivation, self-responsibility, discipline, it updates course content and so gives new life to established courses. In (Pinto-Llorente et al., 2016) research, the students highlighted the opportunity provided to have a greater autonomy to be able to set and organize their own pace of study and individual learning. It can be concluded that in blended learning, there are several benefits that cannot be obtained in the conventional learning model or face-to-face model, such as the unlimited time and place of learning, students' autonomy to set their own pace of study, and the digital fluency enhancement.

Encountering the increase of technology and knowing the benefits of blended learning model, many higher education institutions start applying blended learning in their teaching and learning process. Universitas Negeri Semarang (UNNES) is one of the higher education institutions that encourages its lecturers and students to use Elena (UNNES e-learning system) or other Learning Management System (LMS) for implementing the blended learning model in the teaching and learning process. As mentioned in Rector UNNES regulation No 27 Year 2016 on the implementation of e-learning in UNNES, the use of e-learning aims to improve the efficiency and effectiveness of learning for the students by utilizing network-based information and communication technology. Besides, e-learning is used as a conventional learning complement. Based on the rector's decision, the academic community within UNNES is expected to apply the e-learning model to conventional learning which is called the blended learning model. From the 16 face-to-face meetings in a classroom, the lecturers are required to have 4 meetings online learning. In Faculty of Engineering UNNES, the regulation of using online learning has started since 2018. During the implementation, there should be many challenges and obstacles. English for Specific Purposes (ESP) class is also one of the subjects that integrating online learning in its conventional leaning model. ESP is one of mandatory subjects for all engineering students that should be taken on the first year.

The purpose of this research is to reveal the students' perception during their learning activity in ESP class that applied blended learning model. Previous research in students' perception on blended learning have been done and resulted in positive responses from the students. Most of the students are pleased to join in the blended learning model since it is easy to use and has flexibility (Krasnova, 2016;
Alaidarous \& Madini, 2016; Kharb \& Samanta, 2016; (Varthis \& Anderson, 2016); Ali \& Sofa, 2018). It also positively impacts the students' achievement at the end of the class (Anaraki, 2018; Warman, 2018; Page et al., 2019). Moreover, it increases the students' interest and motivation to learn (Wright, 2017). However, several problems and obstacles faced on the implementation of blended learning, like the limited internet connection and facilities for accessing the blended learning, also the lack of technological skills from the students (Gyamfi \& Gyaase, 2015; Ma'arop \& Embi, 2016).

The ESP class tends to be different from general English class. In ESP class, the student is the centered of learning since the material and the method used are based on the student's needs and purposes for studying English (Baghban, 2011; Rajkhowa \& Borah, 2015). In Faculty of Engineering UNNES, the ESP class aims to prepare the students' English skills to be ready to face the competition in the working world in accordance with their major studies. Usually, the students in ESP class have limited time to learn and practice their English skills in face-to-face class (Nurmasitah, Faridi, \& Utomo, 2018). Therefore, blended learning models had been applied to encounter the limited time of learning problem. They were asked to do self-learning or assignments and online discussion in some topics by using Elena or other LMS, then they had deepened comprehension through peer discussion and problem-solving activities in the face-to-face class

\section{METHOD}

This study was descriptive research that collected the data by using questionnaire. Three classes of undergraduate student at Faculty of Engineering participated in this research. These 145 students were enrolled in ESP class in 2018. This ESP class applied blended learning model using Elena and Google Classroom. Likert scale questionnaire was used to collect the data of the students' perception about their experience in joining the blended learning model in ESP class. The questionnaire was delivered to the students via Google form. A questionnaire was designed by the researchers and validated by the expert faculties. The scoring for the questionnaire was established following the five-point Likert scale: strongly disagree, disagree, neutral, agree, and strongly agree. 


\section{RESULT AND DISCUSSION}

\subsection{Students' perception towards the facilities to support the implementation of blended learning model}

In implementing blended learning model, lecturers and students must be supported by adequate facilities in campus. UNNES campus provides the lecturers and students with an internet access and electronic devices, like computer and laptop, in several location. The lecturers and students of UNNES have an access to use the internet and electronic devices by entering the special code. Table 1 shows the result of students' perception towards the facilities to support the implementation of blended learning model.

The result in table 1 describes that $51.7 \%$ of students strongly agree, $33.8 \%$ agree, and $14.5 \%$ neutral on the first statement. It means that most of them use their own electronic devices to do the blended learning, they do not use the facilities provided in campus. It is because they feel more comfortable and used to work in their own device, or the limited number of electronic devices provided in campus. On the second statement, it indicates that internet café is no longer popular place among the students for getting the internet access. The result shows $57.9 \%$ strongly disagree, $20 \%$ disagree, $13.8 \%$ neutral, $4.8 \%$ agree, and $3.4 \%$ strongly disagree. Moreover, some students use internet access in campus to do the blended learning. It is showed on the result of the third statement; $37.2 \%$ agree, $31 \%$ neutral, $23.4 \%$ strongly agree, $6.9 \%$ disagree, and $1.4 \%$ strongly disagree. When the students use their electronic devices to access the internet, they most probably need electricity or socket outlet to keep their devices on. The result also shows that $30.3 \%$ of student responded neutral, $27.6 \%$ agree, $26.2 \%$ strongly agree, $9.7 \%$ disagree, and $6.2 \%$ strongly disagree. It indicates that campus has internet network. However, the students still do not assume that it has good internet connection.

\subsection{Students' perception on the implementation of blended learning model}

After joining the blended learning model, the students were asked to give their perception of their experience in participating in blended learning model. The results of student responses to the distributed questionnaire can be seen in the table 2 .

The students' responses to the learning of the blended learning model can be seen in table 2 above. From the table, it can be seen that most students still respond neutral $(\mathrm{N})$ to some of the statements submitted; learning motivation $(39.3 \%)$, easier understanding (46.9\%), flexible learning hours (35.9\%), communication with lecturers more flexible (33.1\%), more comfortable communicating with lecturers through online learning $(36.6 \%)$, interaction with fellow students are more interactive $(37.2 \%)$, and enjoy blended learning more than face-to-face models $(47.6 \%)$

However, there were several statements that were responded by students with a large number of agreed (A) statements, namely on statements; the material provided in the E-learning or blended learning model is complete and systematic, and becomes more independent in learning independence. Whereas the statement "by learning the E-learning or Blended Learning model, I save more time and money in learning" gets the most response to strongly agree (SA), which is as much as $40 \%$.

Based on the response data, it can be said that the application of blended learning received a positive response in several ways, namely the practicality of sharing material, independent learning, and saving time and costs in the learning process. In terms of material distribution, students can directly access material provided by lecturers in LMS and Elena, without having to have difficulty finding such material in the form of hardcopy, such as books, journals, or papers. This shows that by implementing blended learning, lecturers can easily and unlimitedly share material. Anyone can access the material by logging into LMS or Elena. In addition, in terms of learning independence, students can do their own learning because the material used is already accessible in LMS or Elena. Students can learn it anytime and anywhere, thus saving more time and money because they do not need to come to class to do learning. Students only need to open electronic devices and access the internet to be able to do learning.

However, students still considered neutral on several matters relating to the application of this blended learning. Students still cannot have strong motivation to learn if they have to study alone without face to face with the lecturer. In addition, students also cannot understand easily if they have to study the material provided by the lecturer 
Table 1. Students' perception towards the facilities to support the implementation of blended learning model

\begin{tabular}{clccccc}
\hline No & \multicolumn{1}{c}{ Statement } & SD & D & N & A & SA \\
\hline 1 & $\begin{array}{l}\text { I use my own mobile phone or laptop } \\
\text { to do the blended learning model. }\end{array}$ & $0 \%$ & $0 \%$ & $14.5 \%$ & $33.8 \%$ & $51.7 \%$ \\
2 & $\begin{array}{l}\text { I go to internet café to get an internet } \\
\text { access in doing the blended learning } \\
\text { model. }\end{array}$ & $57.9 \%$ & $20 \%$ & $13.8 \%$ & $4.8 \%$ & $3.4 \%$ \\
3 & $\begin{array}{l}\text { For doing the blended learning model, } \\
\text { I use internet in campus. }\end{array}$ & $1.4 \%$ & $6.9 \%$ & $31 \%$ & $37.2 \%$ & $23.4 \%$ \\
4 & $\begin{array}{l}\text { Campus provides electricity/ socket } \\
\text { outlets for electronic devices used by } \\
\text { students. }\end{array}$ & $1.4 \%$ & $6.2 \%$ & $17.9 \%$ & $31 \%$ & $43.4 \%$ \\
\hline $\begin{array}{l}\text { Campus has a good Wi-Fi/ internet } \\
\text { network. }\end{array}$ & $6.2 \%$ & $9.7 \%$ & $30.3 \%$ & $27.6 \%$ & $26.2 \%$ \\
\hline
\end{tabular}

themselves. Usually, in face-to-face learning, the lecturer will explain the material directly, which is then followed by giving concrete examples of the material, and students can directly ask the lecturer in question. Questions from student questions that are asked will automatically be directly discussed in class so students can get the answers right away. But it is different in reality if applying an online model or blended learning, students must understand the material that has been shared by the lecturer. If a problem or question arises, students must find their own solutions and answers. There are discussion sessions with lecturers online, but sometimes the lecturer does not answer them directly and students must understand the answers written themselves, not verbally. There are some characters of students who easily understand something that is conveyed orally, not written, so the online discussion model is a bit difficult for the student. So, it can be concluded, that there are still some students who have not been able to enjoy and accept this blended learning model, because they are still familiar with the face-to-face model that has been done so far.

Table 2. Students' perception on the implementation of blended learning model.

\begin{tabular}{|c|c|c|c|c|c|c|}
\hline No & Statement & SD & D & $\mathbf{N}$ & $\mathbf{A}$ & $\mathbf{S A}$ \\
\hline 1 & $\begin{array}{l}\text { I am highly motivated to learn when } \\
\text { using blended learning model. }\end{array}$ & $0 \%$ & $6.2 \%$ & $39.3 \%$ & $35.2 \%$ & $19.3 \%$ \\
\hline 2 & $\begin{array}{l}\text { I can easily understand the material } \\
\text { when using blended learning model. }\end{array}$ & $2.1 \%$ & $9.7 \%$ & $46.9 \%$ & $31 \%$ & $10.3 \%$ \\
\hline 3 & $\begin{array}{l}\text { The material provided in the blended } \\
\text { learning model is complete and } \\
\text { systematic. }\end{array}$ & $0 \%$ & $4.1 \%$ & $39.3 \%$ & $40.7 \%$ & $15.9 \%$ \\
\hline 4 & $\begin{array}{l}\text { By using the blended learning model, I } \\
\text { save more time and cost. }\end{array}$ & $0 \%$ & $1.4 \%$ & $21.4 \%$ & $37.2 \%$ & $40 \%$ \\
\hline 5 & $\begin{array}{l}\text { I find it easier to manage my study } \\
\text { hours after the lecturer applies the } \\
\text { Blended Learning model. }\end{array}$ & $0.7 \%$ & $5.5 \%$ & $35.9 \%$ & $35.2 \%$ & $22.8 \%$ \\
\hline 6 & $\begin{array}{l}\text { The time to communicate with the } \\
\text { lecturer becomes unlimited. }\end{array}$ & $2.1 \%$ & $10.3 \%$ & $33.1 \%$ & $32.4 \%$ & $22.1 \%$ \\
\hline 7 & $\begin{array}{l}\text { I feel more comfortable when having } \\
\text { communication with lecturers in } \\
\text { blended learning model rather than } \\
\text { meeting face to face. }\end{array}$ & $3.4 \%$ & $19.3 \%$ & $36.6 \%$ & $27.6 \%$ & $13.1 \%$ \\
\hline 8 & $\begin{array}{l}\text { Blended Learning model makes } \\
\text { interaction with fellow students easier. }\end{array}$ & $0 \%$ & $9.7 \%$ & $37.2 \%$ & $28.3 \%$ & $24.8 \%$ \\
\hline 9 & $\begin{array}{l}\text { By using blended learning model, I } \\
\text { become more independent in learning. }\end{array}$ & $0.7 \%$ & $2.8 \%$ & $34.5 \%$ & $39.3 \%$ & $22.8 \%$ \\
\hline 10 & $\begin{array}{l}\text { I enjoy blended learning model more } \\
\text { than conventional models (face-to-face } \\
\text { in the classroom). }\end{array}$ & $2.8 \%$ & $16.6 \%$ & $47.6 \%$ & $20 \%$ & $13.1 \%$ \\
\hline
\end{tabular}




\section{CONCLUSIONS}

From the results and the previous discussion, it can be concluded several things related to the application of the blended learning model as follows;

a. The application of blended learning received a positive response in several ways, namely the practicality of sharing material, independent learning, and saving time and costs in the learning process.

b. Students still cannot have strong motivation to learn if they have to study alone without face to face with the lecturer.

c. Students cannot understand easily if they have to do self-study of the material provided.

d. Some students have not been able to enjoy and accept blended learning model, since they used to the face-to-face model that has been done so far.

\section{REFERENCES}

Alaidarous, K., \& Madini, A. A. (2016). Exploring Efl S Tudents' Perception in Blended Learning Environment in Saudi Technical Education Context. International Journal of Educational Investigations, 3(6), 69-81.

Ali, F., Sofa, E. M. (2018). Students' Perceptions of The Implementation of Blended Learning in A Large English Class. Edulitics Journal, 3(1), 15-28.

Anaraki, F. (2018). The Effectiveness of Blended Learning: A Case Study. 38(2), 82-93.

Ardana, I. M., Ariawan, I. P. W., Divayana, D. G. H. (2016). Development of Decision Support System to Selection of The Blended Learning Platforms for Mathematics and Ict Learning at Smk Ti Udayana. International Journal of Advanced Research in Artificial Intelligence, 5(12), 15-18.

Baghban, Z. Z. V. (2011). A Review on The Effectiveness of Using Authentic Materials in Esp Courses. English For Specific Purposes World, 10(31), 1-14.

Boelens, R; Laer, S. V; Wever, B. D; Elen, J. (2015). Blended Learning in Adult Education: Towards A Definition of Blended Learning. Https://Doi.Org/10.2307/4022859

Editors, A., Billings, D. M., Shatto, A. B., \& Erwin, K. (2016). Moving on From Millennials: Preparing for Generation Z. 47(6), 253-254. Https://Doi.Org/10.3928/00220124-20160518-05

El-Zeftawy, M.A., Hassan, L. A. E. A. E. (2017). Perception of Students Regarding Blended Learning Implementation of Community Health Nursing Course at Faculty of Nursing, Tanta University, Egypt. Journal of Nursing Education and Practice, 7(3). Https://Doi.Org/10.5430/Jnep.V7n3p83
Grace, M. (2017). Generation Z: Educating and Engaging the Next Generation of Students. (August), 21-26. Https://Doi.Org/10.1002/Abc.21293

Gyamfi, S. A., Gyaase, P. O. (2015). Students' Perception of Blended Learning Environment: A Case Study of The University of Education, Winneba, KumasiCampus, Ghana. International Journal of Education and Development Using Information and Communication Technology, 11(1), 80-100.

Hilliard, A. T. (2015). Global Blended Learning Practices for Teaching and Learning, Leadership And. 11(3), 179-188.

Kharb, P., \& Samanta, P. P. (2016). Journal of The Anatomical Society of India Blended Learning Approach for Teaching and Learning Anatomy: Students' and Teachers' Perspective. Indian Journal of Rheumatology, 65(1), 43-47. Https://Doi.Org/10.1016/J.Jasi.2016.06.001

Krasnova, T. (2016). Blended Learning Perception Among Undergraduate Engineering Students. (February), 4-7. Https://Doi.Org/10.3991/Ijet.V11i01.4901

Lalima And Dangwal, K. L. (2017). Blended Learning: An Innovative Approach. Universal Journal of Educational Research, 5(1), 129-136. Https://Doi.Org/10.13189/Ujer.2017.050116

Ma'arop, A. H., \& Embi, M. A. (2016). Implementation of Blended Learning in Higher Learning Institutions: A Review of The Literature. International Education Studies, 9(3), 41-52. Https://Doi.Org/10.5539/Ies.V9n3p41

Nurmasitah, S., Faridi, A., \& Utomo, A. B. (2018). The Efficacy of Focus Group Discussion in Teaching Esp Speaking Skill for Prospective Vocational School Teacher the Efficacy of Focus Group Discussion in Teaching Esp Speaking Skill for Prospective Vocational School Teacher. Aip Conference Proceedings 1941, 020054(March). Https://Doi.Org/Https://Doi.Org/10.1063/1.5028112

O'flaherty, J., \& Phillips, C. (2015). The Use of Flipped Classrooms in Higher Education: A Scoping Review. Internet and Higher Education, 25, 85-95. Https://Doi.Org/10.1016/J.Iheduc.2015.02.002

Page, J., Meehan-Andrews, T., Weerakkody, N., Hughes, D. L., \& Rathner, J. A. (2019). Student Perceptions and Learning Outcomes of Blended Learning in A Massive First-Year Core Physiology for Allied Health Subjects. 44-55. Https://Doi.Org/10.1152/Advan.00005.2016

Pinto-Llorente, A. M., Sanchez-Gomez, M. C., GarcíaPenalvo, F. J., Sonia, C. (2016). Computers in Human Behavior Students' Perceptions and Attitudes Towards Asynchronous Technological Tools in BlendedLearning Training to Improve Grammatical Competence in English As A Second Language Nchez$\mathrm{G}$ O. Computers in Human Behavior. Https://Doi.Org/10.1016/J.Chb.2016.05.071

Puncreobutr, V. (2016). Education 4.0: New Challenge of Learning. Humanitarian and Socio-Economic Sciences, 2(2), 92-97. Retrieved from Http://Scopuseu.Com/Scopus/Index.Php/Hum-SeSc/Article/View/188 
Rajkhowa, B., \& Borah, N. (2015). Developing Communicative Competence of Engineering Students Through English For Specific Purpose (Esp.). 3(2), $115-116$.

Varthis, S., \& Anderson, O. R. (2016). Students'

Perceptions of a Blended Learning Experience in Dental Education. (November), 1-7. Https://Doi.Org/10.1111/Eje.12253

Warman, L. A. D. (2018). Students' Perception of Using Whatsapp In Blended Learning on Reading Comprehension. Journal of English For Academic, $5(2), 27-38$.

Wright, B. M. (2017). Blended Learning: Student Perception of Face-To-Face and Online Efl Lessons. 7(1), 64-71.

Shatto, A. B., \& Erwin, K. (2016). Moving on From Millennials: Preparing for Generation Z. 47(6), 253254. Https://Doi.Org/10.3928/00220124-20160518-05. 